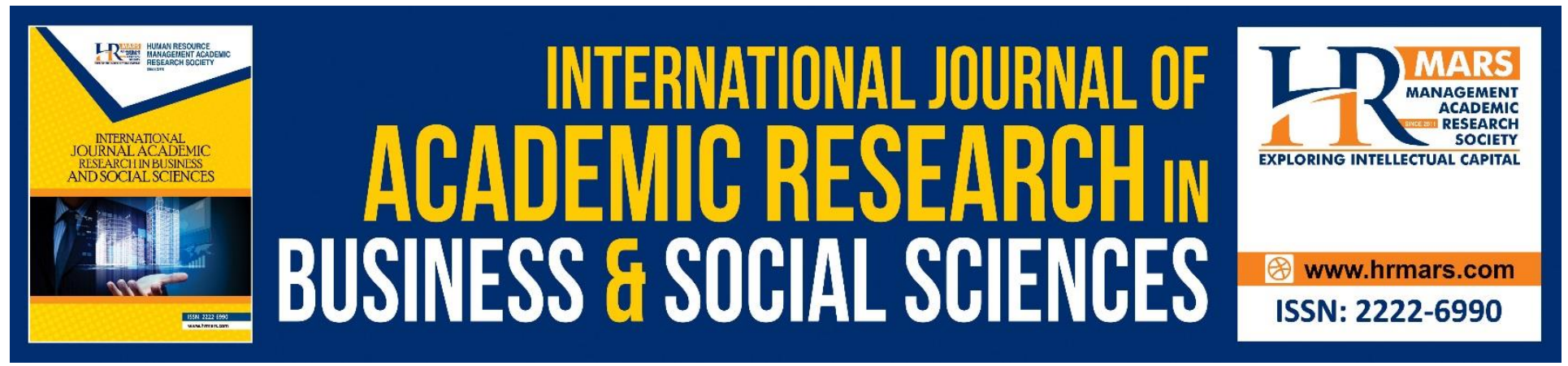

\title{
Evaluation of the Implementation of Air Force Staffing Programme at the Air Force Personnel Administration Service, Air Force Headquarters, Cilangkap
}

Syamsunasir, Mahmuddin Yasin, Yetti Supriyati

To Link this Article: http://dx.doi.org/10.6007/IJARBSS/v10-i14/7683

DOI:10.6007/IJARBSS/v10-i14/7683

Received: 07 April 2020, Revised: 11 May 2020, Accepted: 15 June 2020

Published Online: 27 July 2020

In-Text Citation: (Syamsunasir et al., 2020)

To Cite this Article: Syamsunasir, Yasin, M., \& Supriyati, Y. (2020). Evaluation of the Implementation of Air Force Staffing Programme at the Air Force Personnel Administration Service, Air Force Headquarters, Cilangkap. International Journal of Academic Research in Business and Social Science, 10(14), 134-144.

Copyright: (c) 2020 The Author(s)

Published by Human Resource Management Academic Research Society (www.hrmars.com)

This article is published under the Creative Commons Attribution (CC BY 4.0) license. Anyone may reproduce, distribute, translate and create derivative works of this article (for both commercial and non-commercial purposes), subject to full attribution to the original publication and authors. The full terms of this license may be seen at: http://creativecommons.org/licences/by/4.0/legalcode

Special Issue: WSTI2018 - Issues and Trends on Education, Science and Technology, 2020, Pg. 134 - 144 http://hrmars.com/index.php/pages/detail/IJARBSS

Full Terms \& Conditions of access and use can be found at http://hrmars.com/index.php/pages/detail/publication-ethics 


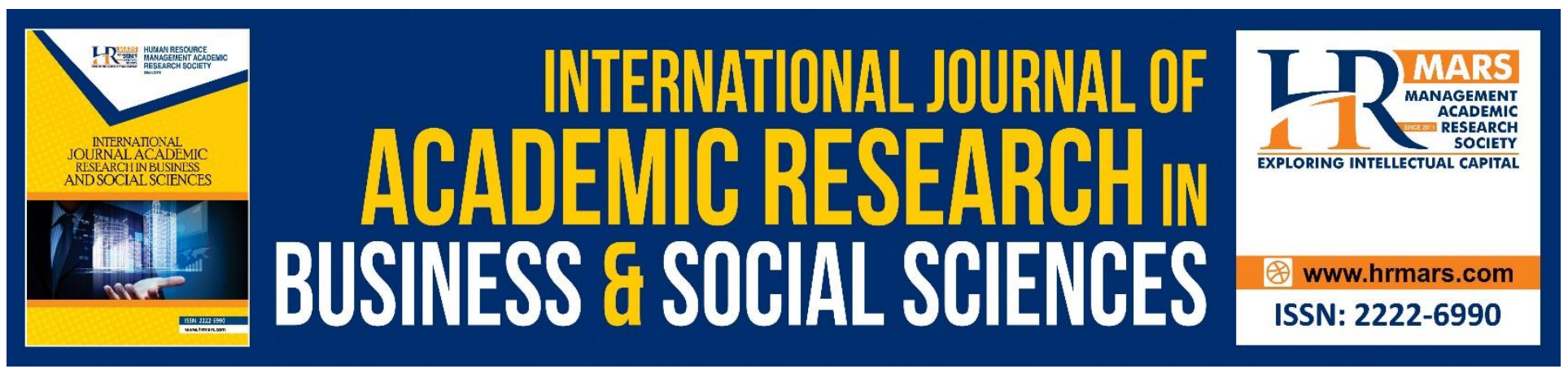

\title{
Evaluation of the Implementation of Air Force Staffing Programme at the Air Force Personnel Administration Service, Air Force Headquarters, Cilangkap
}

\author{
Syamsunasir, Mahmuddin Yasin, Yetti Supriyati \\ State University of Jakarta, Indonesia
}

\begin{abstract}
This research aims to evaluate the implementation process of the Air Force (TNI AU) staffing programme at the Air Force Personnel Administration Service (Disminpersau), Air Force Headquarters (Mabesau), Cilangkap. The research was conducted through an evaluative study with the CIPPO model. The results show that: (1) the implementation of the programme has conformed with laws; programme objectives and targets in the quality and quantity aspects were met successfully; (2) the committee and officers have met the provisions under the technical guidelines; however, computer labs for administering CAT were insufficient; (3) test-takers were disqualified for a number of reasons, including mistakes in the document submission for administrative purpose, exceeding maximum age requirement, having below-average intelligence, having low endurance, having low stress tolerance, being pliable, having ear-nose-throat (ENT) disease(s) or disorder(s), having colour blindness, having lung disease(s), being unable to swim, having ear piercing(s), having weak loyalty towards the Five Principles (Pancasila), the Unitary State of Indonesia (NKRI) and the 1945 Constitution (UUD 1945), being engaged in radicalism, having free sex and being vigilant; (4) the pass of the candidates is based on the final score, and the candidates are deployed at all Air Force corps; (5) the cost benefit achieved includes the contribution towards airspace security, integrity and individual capabilities in performing jobs. When it comes to quality, some officers were still unable to fly combat aircrafts and, thus, transferred to other specialties.
\end{abstract}

\section{Introduction}

The Air Force Personnel Administration Service, in Bahasa Indonesia abbreviated to Disminpersau, is a central executing body at the air force headquarters (Mabesau) level precisely under the supervision of the Chief of Staff (Kasau) who is responsible for the management, implementation and control of personnel administration, including some personnel management functions such as the staffing, education, employment, separation, preparation and transfer of Air Force personnel as well as management of profession, administration and special services. The recruitment of cadets of the Academy is organized through the founding of a temporary organisation with some elements, which functionally have a direct relation to the candidate selection. 
The results of the preliminary survey of the Air Force staffing programme implementation describe that the programme, having been run from 2011 to 2016, has produced more than 549 Air Force officers. The results also provide an illustration of some problems relating to poor recruitment and selection processes in the Air Force staffing programme at Disminpersau Cilangkap Jakarta, including the following: (1) the planning of the recruitment programme was not thorough and focused, and the implementation was not consistent; (2) the recruitment preparation and committee establishment at the central and regional levels were not conducted optimally; (3) the monitoring and evaluation functions as components of quality assurance were not performed optimally; (4) the selection process including psychological test, medical examination, military physical and posture test, Air Force Military Police Command (Pomau) screening and personnel checking were not optimum; (5) the targeted number of Air Force officers required to staff the organisation was not met; and (6) there were some performance-related complaints from officers users and management institutions.

Another problem arose when some candidates who were declared passing at the regional level were declared failing at the national level despite retaking exactly the same test. This proved that some problems were present during the selection process. Given that, it is deemed necessary to conduct research on the implementation of the Air Force staffing programme at Disminpersau Mabesau Cilangkap Jakarta.

\section{Theoretical Review}

\section{Programme Evaluation Concept}

Program evaluation constitutes the first step of supervision. Appropriate data should be collected to be followed up with suitable management. Carpenter (2016) defines programme evaluation as an effort to conduct analysis, collect data in the field and find information in the field. McDavid, Huse and Hawthorn (2013) state that programme evaluation is a systematic process of assessing a programme or policy based on absolute criteria (merit-based) or relative criteria (worthbased). Goodier et al., (2017) state that programme evaluation is performed to look into the efficiency, implementation, outcomes and costs of a programme. Similar to those definitions, Andrew Topper and Lancaster (2016) state that programme evaluation is required to examine an evaluation model or approach to determine the most appropriate planning model to apply.

According to the opinions above, the definition of programme evaluation can be synthesised as an activity that is carried out in a systematic manner, starting from collecting, organising, processing to analysing data or information on a programme based on appropriate evaluation criteria or measures as the basis for a decision on the programme for its betterment, improvement and development as well as a decision on whether the programme should carry on or perish.

\section{Recruitment}

There are some definitions of recruitment offered. According to Greenhouse (2006), recruitment is conventionally defined as an organisational activity aimed to draw potential. Similarly, Amstrong (2006) states that recruitment is related to an addition of required quantity and types. Noe defines recruitment as a process of seeking potential job.

According to the definitions presented above, the definition of recruitment can be synthesised as the selection and hiring of an individual to fill a particular position or role. In the 
context of Air Force officer development, recruitment refers to the procurement of good-quality officers to complete a formation.

\section{Selection}

Selection is a crucial function because it serves as an organisation's way to obtain a wide range of expertises to achieve its goals. According to Goldstein (2017), selection is a process of choosing new members to jointly achieve the goals of an organisation. Siagian (2007) states that employee selection process is an extremely important part of human resources management process. A selection process starts with application receipt and ends with a decision on the application. He also mentioned some criteria of selection, including past performance and past experience.

According to the opinions above, it can be concluded that Air Force officer candidate selection can be generally defined as an effort to find and provide potential, good-quality Air Force officers that best suit the existing needs and are able to work professionally pursuant to the prevailing provisions in accordance with their responsibilities for the government/authority to hire.

\section{Air Force Staffing Concept}

According to the Air Force Staffing Plan Number B/401 1-08/02/19/Disminpersau (2018), staffing is part of the management of the Armed Forces personnel, notably the Air Force personnel, which essentially is intended to find officer candidates that meet the quality and quantity requirements to fulfil the needs arising during the execution of the Air Force's main tasks.

According to the Air Force Academy Cadet Recruitment Plan (2014), staffing as part of the personnel management system in addition to education, employment, maintenance and separation of personnel essentially refers to an effort, activity and work to find Air Force officers in predetermined quality and quantity to fulfil the organisation's staffing needs.

\section{CIPPO Model in the Evaluation of Air Force Staffing Policy}

CIPPO is a modification of the CIPP model. The CIPP model has been refined with an addition of $\mathrm{O}$, which stands for Outcome, and becomes CIPPO. The CIPP model ends with measurement (Product), while the CIPPO model goes further to the implementation of a product. The authors chose the CIPPO model as it is deemed as the most appropriate and effective model according to the analysis of this evaluation model and the research objectives. This model fits the research's sub-focus, is holistic and systematic, is able to explore the rationale for the policy implementation (in the context evaluation) and generates recommendations in the decision-making at every level. The CIPPO model consists of five evaluation components, namely context evaluation, input evaluation, process evaluation, product evaluation and outcome evaluation.

\section{Context Evaluation}

Context evaluation is intended to answer this question: what need to be done? This evaluation identifies and assesses the needs that lead to the design of a programme/policy.

\section{Input Evaluation}

Decision makers conduct input evaluation to choose between the existing plans, conceive funding proposals, allocate sources, conduct staffing, schedule works, assess activity plans and conduct budgeting. According to Stufflebeam and Coryn (2014), input evaluation helps 
identify and assess competitive strategies and programme procedural design to meet receiver-assessed needs.

\section{Process Evaluation}

Process evaluation is an effort to seek answers for the question of whether the programme is executed from the planning to help the staff conduct their activities and help general users judge the programme and interpret the benefits. Stufflebeam and Coryn (2014) state that process evaluation involves documentation and assessment of the implementation of a select programme strategy.

\section{Product Evaluation}

According to Stufflebeam and Coryn (2014), this evaluation seeks to identify and access the output and benefits, both planned and unplanned, in the short-term or in the long-term. Both help the staff stay focused in reaping the benefits and ultimately assist general users in measuring the success of the effort to meet their targets.

\section{Outcome evaluation}

Outcome evaluation refers to the evaluation of the output of a programme implementation and the extent of benefits offered by the Air Force officer selection programme at Disminpersau Mabesau Cilangkap Jakarta.

\section{Research Method}

The method selected in this research is the programme/policy evaluation method. Some components were evaluated using the CIPPO model in the order of context evaluation, input evaluation, process evaluation, product evaluation and outcome evaluation. The key informants in this research comprised Chief of Staff Assistant, Governor of Air Force Academy, Air Force Staffing Committee members and Air Force officers. Data were collected through interviews, documentation and observations.

\section{Research Results and Discussion Context Evaluation \\ Legal Basis}

The Air Force staffing programme at Disminpersau Mabesau Cilangkap is in accordance with the legal basis at the implementation level for the purpose of meeting Armed Forces human resources needs. The legal basis and policies on the staffing programme used as references for the programme implementation includes the activity technical guidelines and the Letter of the Defence Minister on the Yearly Plan for the Army, the Navy and the Air Force Staffing.

\section{Objective}

Air Force staffing as one of the activities of Air Force personnel management aims to meet the staffing needs and improve the Air Force capabilities. The objective is to produce future Air Force officers/leaders who are able to respond to technological challenges in the coming days to guard the sovereignty of the Unitary State of Indonesia (NKRI) within the airspace. This is in line with the Air Force's main responsibility. 


\section{Program Targets}

The programme's target achievement was apparent in the meeting of Air Force officer requirement. The target was to meet the quality and quantity requirements of human resources prepared for the Air Force's organisation future. This target was met by promoting airmen staffing via online media, improving the facilities and infrastructure for airmen staffing and improving the quality of airmen recruitment/staffing by increasing the transparency and objectivity in the examination.

Air force staffing is targeted at meeting the needs for officers based on the needs plan and Air Force strength establishment plan, including (1) establishing fighting spirit, valiance discipline as well as complete and solid courageous fighter and fighting warrior personalities based on the Sevenfold Ways (Sapta Marga) and the Soldier's Oaths (Sumpah Perwira); (2) establishing organisation order and balance; (3) establishing officer professionalism based on the tasks and roles; (4) establishing civil-military relations; (5) determining the quality and quantity of human resources requirement for organisational purpose as well as development and employment through human resources efficiency study.

\section{Input Evaluation}

\section{Officer Standards}

In the selection process, the committee set several standards that must be met by an individual to be an Air Force officer. The standards are as follows:

$\begin{array}{lll}\text { Administration B/K1 } & \geq & 41 \\ \text { POM screening MS/K1 } & \geq & 41 \\ \text { Personnel checking MS } & > & 40 \\ \text { Health examination B/C/K1 } & > & 55 \\ \text { Psychological test B/C/K1 } & \geq & 41 \\ \text { Physical test B/C/K1 } & \geq & 38 \\ \text { Academic test B/C/K1 } & \geq & 55\end{array}$

An officer must meet the abovementioned standards so as to reach the expected quality. In the event of non-fulfilment of any one of the abovementioned standards, the candidate will definitely be disqualified from taking futher tests.

\section{Committee Standards}

Each committee member must have the qualifications/capabilities in their respective selection area. According to the provisions under the technical guidelines on the officer recruitment, the committee (1) supervise the staffing programme implementation, (2) plan the examination based on each area, (3) report the examination results, (4) are responsible, (4) are open-minded and (6) have integrity. The standards set for committee members are regulated under the technical guidelines, and committee members are selected based on the applicable criteria.

\section{Facility and Infrastructure Availability for the Selection Process}

A weakness in terms of facility and infrastructure provision was found. It was found out that computer labs for administering CAT were not available in a sufficient quantity. The committee 
coordinated with side units to fill the gap in the facility and infrastructure availability for selection purpose. Facilities and infrastructure, especially in remote areas, were limited in quantity.

\section{Funding for Programme Implementation}

Every need in the Air Force staffing programme implementation was financed constantly. The committee still faced some stumble blocks in designing and implementing the programme. However, they constantly worked with the Chief of Planning and Budgeting Staff Division (Asrena Kasau) through the Head of Programme and Budgetting (Kaprogar) of Disminpersau to propose for additional funds for the selection. The budget allocated for meeting the Air Force staffing needs comprises the following: (1) operating cost for staffing purpose, (2) meal allowance and (3) tactical cost.

\section{Process Evaluation}

\section{Administrative Examination}

Administrative examination is the first step in the admission test. This examination is administered in two parts, namely national-level test and regional-level test. At the national level, this examination is administered by the Sub-Service Head (Kasubdis), Field Grade Officer (Pamen), Company Grade Officer (Pama) and Disminpersau members. Meanwhile, at the regional level, the test is administered by the Personnel Service Chief (Kadispers), Personnel Management Section Chief (Kasibinpers)/Administration and Personnel Staff Chief (Kasiminpers) and local airport staff members. Online registration is performed in the following stages: (1) directly registering to a personnel staff member of a local airport; (2) submitting documents to a personnel officer; (3) checking document completeness; and (4) announcing the results of the administrative examination.

Some of the research findings reveal that in the administrative examination process, there are a number of reasons for cadidates' failure, including exceeding the maximum age requirement and some mistakes in the document submission for administrative purpose, for example, incorrect document conception, missing number and date of document legalisation, non-attachment of lost item report for lost graduation certificate, signature by a guardian while parents are still alive, missing collusion-free statement letter, self-signed parents' consent, missing cover letter, wrong mother's name in the certificate and family card data mismatch.

According to the Air Force Technical Guidelines on the Staffing Administrative Examination and Assessment (2013), Air Force staffing must meet not only the general requirements specified under the Law Number 34 of 2004 on the Indonesian National Armed Forces but also the specific requirements and additional requirements set according to the needs of the Air Force. It is necessary to conduct administrative examination to uniformise data completeness and validity.

\section{Psychological Test}

For the psychological test, the committee set a number of aspects candidates must pass: (1) motivation; (2) interest; (3) potential; (4) intelligence structure and function; (5) emotional stability; (6) work attitude; (7) sociability and (8) leadership. With regard to the aforementioned aspects, some reasons for candidates' failure in psychological test include below-average intelligence, low endurance, low tolerance to stress, inefficient work and pliability. 


\section{Health Examination}

Health examination becomes one of the most important parts of the selection process. Air Force officer candidates are expected to meet health requirements and pass some tests, including health administration, general examination, surgical examination, dermatology examination, internal examination, eye examination, ENT examination, oral cavity examination, lung examination, heart examination, radiology examination, laboratory examination and mental health examination.

In relation to health examination, candidates' failure can be caused by ENT diseases or disorders, colour blindness or lung diseases. Health examination should be conducted uniformly at every implementation element to obtain uniform results.

\section{Military Physical and Posture Test}

Military physical test should be conducted uniformly at every element to obtain uniform results. This test is intended to recruit Academy cadets who have physical condition, posture and agility that meet the requirement. Officers should have physique and posture that meet the requirements for Air Force officers regarding physique and posture and should pass the following: body height and weight measurement, anatomical structure defect examination, body type observation, attitude, movement and appearance observation and swimming skill test.

Candidates' failure in the military physical and posture test can be caused by a number of reasons: candidates are unable to swim and have extreme posture abnormality. According to the Air Force Technical Guidelines on the Air Force Academy Cadet Recruitment (2010), physical test is administered by the physical test team at the regional and national levels, and in its administration the following must be considered: (1) posture examination, including body height and weight measurement, anatomical structure defect examination, body type observation and attitude, movement and appearance observation; (2) physical test, including physical test A, physical test and swimming skill test.

\section{Pomau Screening}

Pomau screening is conducted on a gradual basis from the regional level to the national level. The purpose of Pomau screening is to examine the validity of administrative letters and documents to avoid legal issues in the future.

With regard to Pomau screening, some problems were found, including candidates having ear piercing, some differences between elementary school, middle school and high school graduation certificates and double family cards. Pomau screening is generally performed by the examiner team at the regional and national levels, but dactyloscopy, final interview and criminal preliminary investigation are only performed by the examiner team at the national level.

\section{Personnel Assay}

According to the Air Force Technical Guidelines on the Air Force Academy Cadet Recruitment (2016), personnel assay is conducted in accordance with the Air Force technical guidelines on personnel assay, including (1) submission of administrative documents by candidates; (2) form completion by candidates; (3) scrutiny and assessment of DIP answers by interviewers; (4) interview with candidates and (5) in-depth assessment.

According to the research results, some candidates were found to have weak loyalty towards Pancasila, the Unitary State of the Republic of Indonesia, the 1945 Constitution and the Government, 
be engaged in radicalism, having free sex and were vigilant, causing them to fail the test. The Air Force Technical Guidelines on Personnel Assay (2012) defines personal assay as any effort, work, activity and action intended to figure out and delve into one's personal life background, attitude and outlook towards ideology, political, social and cultural matters as well as understanding, devotion and loyalty with regard to Pancasila, the 1945 Constitution and the Unitary State of the Republic of Indonesia.

\section{Product Evaluation}

Programme Pass

According to the research results, all candidates had met the predetermined standards and programme. The pass of the candidates is determined by final scores. It is also determined by the Tour of Duty and Tour of Area (TOA/TOD) meeting decision made by the Chief of Staff. All candidates who are declared passing will be deployed at the corps decided by the Air Force across the Unitary State of the Republic of Indonesia at Air Force operating bases.

\section{Outcome Evaluation}

\section{Cost Benefit}

Cost benefit is not always measured materially. It can also be measured immaterially based on officers' contribution towards the Government, especially in guarding the airspace. In this cost benefit aspect, the Air Force officers make a contribution in the form of work, integrity and capability in performing their respective job. The State will benefit from professional, reliable human resources, and the State's objectives will be achieved.

\section{Air Force Officer Quality}

According to the results, the Air Force officers' quality has satisfied the standard. However, there were some officers who were unable to fly combat aircraft. These officers were transfered to other specialties according to their interests and talents and continuously strive to perform the Air Force's main tasks with various challenges ahead. Flyers are expected to not only master flying skills but also all other predetermined specialisations in order to perform their functions/tasks in the organisation. Officers are required to be:

Tanggap (responsive), in that they are able to think fast and accurately to provide solutions to problems;

Tanggon (trustworthy), in that they have meritorious personality and can be role models for fellow members; and

Trengginas (swift), in that they have good physical condition to perform every work they are responsible for as Armed Forces/Police officers.

\section{Conclusions}

\section{Context Evaluation}

The implementation of Air Force staffing programme at Disminpersau Mabesau Cilangkap has conformed the legal basis and the technical guidelines as references. Additionally, the programme objectives and targets in the quality and quantity aspects have been met. 


\section{Input Evaluation}

The officers have met the Air Force's requirements and passed the selection process, which included administrative examination, psychological test, health examination, military physical and posture examination, Pomau screening and personnel assay. The executing committee have also met the standards specified under the technical guidelines in supervising the implementation of staffing programme, planning the examination activity according to respective area, reporting the examination results, being responsible and open-minded and having the integrity. However, there were some things to improve in the facility and infrastructure provision for the selection process, including the availability of computer labs for administering CAT and the availability of facilities and infrastructure in remote areas. As for the financing aspect, the needs arising in the implementation of the Air Force staffing programme have been fulfilled.

\section{Process Evaluation}

The administrative examination was conducted at two levels, namely the national level and the regional level. Some reasons for candidates' failures in the selection process were identified, including the candidates' exceeding the maximum age requirement and mistakes in the document submission for administrative purposes, for example, incorrect document conception, missing number and date of legalisation, non-attachment of report of lost items for lost graduation certificate, signature by a guardian while parents are still alive, missing collusion-free statement, selfsigned parents' concent, missing cover letter, wrong mother's name on the certificate and family card data mismatch.

In the psychological test, failures were caused by the candidates' below-average intelligence, low endurance, low tolerance to stress, inefficient work and pliability. In terms of health examination, candidates failed because they had ENT diseases or disorders, colour blindness and lung diseases. Meanwhile, failures in the physical and posture test was caused by candidates' inability to swim and extreme posture abnormality. Failures in Pomau screening were caused by candidates' having ear piercings, misalignment between elementary school, middle school and high school graduation certificates and double family cards. Finally, candidates failed in the personnel assay because they had low loyalty towards Pancasila, the Unitary State of the Republic of Indonesia, the 1945 Constitution and the Government, were engaged in radicalism, had free sex and were vigilant.

\section{Product Evaluation}

All graduates had met the predetermined standards and programme. Their achievement was based on their final score. It was also based on the Tour of Duty and Tour of Area (TOA/TOD) meeting decisions made by the Chief of Staff. All candidates declared passing could be deployed at the corps determined by the Air Force across the Unitary State of the Republic of Indonesia where Air Force operating bases are.

\section{Outcome Evaluation}

For the Air Force, the cost benefit to be received is the officers' contribution towards the Government, especially in guarding the airspace, demonstrating integrity and displaying individual capabilities in performing their works. The State will benefit from human resources who are professional and reliable in their fields, so the State's objectives can be realized. The Armed Forces officers' quality has met the standard. However, some officers were found unable to fly combat 
aircraft. They would be transfered to other specialties according to their interests and talents to continuously perform the Armed Forces' main task.

\section{References}

Amstrong, M. (2006). A Handbook of human resource management practice. London: Cambridge University.

Andrewe, R., Topper, M., \& Lancaster, S. (2016). Online Graduate Educational Technology Program: An Illuminative Evaluation. Studies in Educational Evaluation, 51, 2016.

Carpenter, J. P. (2016). Assessment of Operational Effectiveness for Education Program Providers. Journal of Assessment and Institutional Effectiveness, 4.

Goldstein, H. W. (2017). The Wiley Blackwell Handbook of the Psychology of Recruitment, Selection and Employee Retention. New York: John Wiley \& Sons, 2017.

Goodier, S., Field, C., \& Goodma, S. (2017). The Need For Theory Evaluation In Global Citizenship Programmes: The Case Of The Gcsa Programme. Evaluation and Program Planning, 66, 2017. Greenhause, J. H. (2006). Encyclopedia career development. London: A Sage Publications, 2006. McDavid, J. C., Huse, I., \& Hawthorn, L. R. (2013). Program Evaluation and Performance Measurement and Introduction to Practice, 2nd Edition: Sage Publication Inc., 2013.

Rencana Pelaksanaan Kegiatan Penyediaan Taruna dan Taruni Akademi Angkatan Udara TA. (2014). Renlakgiat Penyediaan Perwira TNI AU Nomor B/401 1-08/02/19/Disminpersau, 2018.

Russell, S., \& Matthew J. B. (2016). Getting the right people on the bus" recruitment, selection and integration for the branded organization. European Management Journal.

Siagian, S. P. (2007). Manajemen Sumber Daya Manusia. Jakarta: Penerbit Bumi Aksara, 2007. Stufflebeam, D. L., \& Coryn, C. L. S. (2014). Evaluation Theory, Models \& Applications 2 edition. Canada: Wiley. 